\title{
The Socio-Technical Balanced Scorecard for Assessing a Public University
}

Link to publication record in Manchester Research Explorer

\section{Citation for published version (APA):}

Wood-Harper, T., Singh, R., \& Alkhalifa, E. (Ed.) (2011). The Socio-Technical Balanced Scorecard for Assessing a Public University. In E-Strategies for Resource Management Systems: Planning and Implementation (pp. 47-60). IGI Press.

\section{Published in:}

E-Strategies for Resource Management Systems: Planning and Implementation

\section{Citing this paper}

Please note that where the full-text provided on Manchester Research Explorer is the Author Accepted Manuscript or Proof version this may differ from the final Published version. If citing, it is advised that you check and use the publisher's definitive version.

\section{General rights}

Copyright and moral rights for the publications made accessible in the Research Explorer are retained by the authors and/or other copyright owners and it is a condition of accessing publications that users recognise and abide by the legal requirements associated with these rights.

\section{Takedown policy}

If you believe that this document breaches copyright please refer to the University of Manchester's Takedown Procedures [http://man.ac.uk/04Y6Bo] or contact uml.scholarlycommunications@manchester.ac.uk providing relevant details, so we can investigate your claim.

\section{OPEN ACCESS}




\title{
Chapter 3 \\ The Socio-Technical Balanced Scorecard for Assessing a Public University
}

\author{
Ramanjit Singh \\ University of Manchester, UK \\ Trevor Wood-Harper \\ University of Manchester, $U K$
}

\begin{abstract}
The socio-technical theory is concerned with humanistic welfare paradigm. The socio-technical principles aim to improve redundant jobs and thereby benefit human work lives. Hence, jobs are enriched using flexible work methods, empowerment strategies and new technologies. Balanced scorecard is a framework that measures whether the firm is meeting its objectives in terms of vision and strategy. It assesses four perspectives: financial, customer, internal business processes and innovation \& learning. Even though the balanced scorecard has proven to be beneficial in the for-profit organizations of the past, most non-profit organizations were unable to utilize the balanced scorecard. The original configuration of balanced scorecard placed financial goals on the top of the hierarchy and since maximizing shareholder wealth is not the main objective for most non-profit organizations, it was not widely applied by these organizations. Since non-profit organizations usually operate to maximize the well-being of the society, socio-technical work design principles may receive a greater acceptance in these organizations than in for-profit organizations. Thus, a socio-technical balanced scorecard for the non-profit organizations will be formulated with an emphasis on employee perspective and a public university wide assessment will be proposed.
\end{abstract}

\section{INTRODUCTION}

Socio-technical theory is half a century old. It was found by group of researchers, therapists, and consultants at the London Tavistock Clinic to assist

DOI: 10.4018/978-1-61692-016-6.ch003 soldiers for regaining their mental stability and health after the war. The group at Tavistock Clinic believed that treatment ideas used for healings the soldiers could be applied for enriching jobs. In line with this thinking, the Tavistock institute was developed by this group in 1946. The Tavistock institute wanted to merge disciplines such as psy- 
chology and social science in a way that enabled the organization to design jobs that lead to higher job satisfaction. Since the group originated from a therapeutic background, members were interested in "results" and also "theories". This thinking guided them to an approach that was based on action research, which resulted in the remedial changes based upon analysis and theory. The members of the Tavistock institute believed that no theory could be established without practice and no practice could thrive without theoretical influence. Upon the initial success in Britain, the socio-technical drive was internationalized in 1972, with creation of Council for the Quality of Working life. This group compromised of academics from the University of Oslo, University of Pennsylvania, York University, Centre for Continuing Education in Canberra, and the University of Michigan. Together, this group had significant influence on the development of the socio-technical theory (Checkland \& Holwell, 2004; Mumford, 2003, 2006).

In the 1970s, socio-technical theory was widely applied for designing jobs. However, many firms came under pressure during the 1980 s to cut costs and during these circumstances socio-technical ideas were seen as expensive and risky to implement. During 1990s socio-technical design principles continued to struggle, as there was little room for investment in the human capital. The focus was mainly on lean production methods and business process reengineering flourished. A widely accepted methodology which gained corporate awareness during the 1990s is the balanced scorecard (Robert S. Kaplan \& Norton, 1992). The balanced scorecard provides an assessment on the firm's financial position, customer satisfaction, internal processes, and research \& development. In other words, the balanced scorecard provides the manager with information about problems areas and invokes change to correct inconsistencies in the organization. Although the balanced scorecard has been fruitful for the for-profit organizations, its use in the non-profit sector has been rare. The original configuration of balanced scorecard placed the financial goals on the top of the hierarchy but as the non-profit organizations generally function for the well-being of the society and maximizing shareholder wealth is not the main objective, it was not widely applied by these organizations. Hence, a socio-technical balanced scorecard with an emphasis on employee perspective will be developed and proposed for assessing a public university.

\section{HISTORICAL OVERVIEW OF THE SOCIO-TECHNICAL THEORY}

The socio-technical theory was first applied in organizations in the 1970s. It was believed that socio-technical ideas could facilitate the design of jobs in a way that improve human work lives. So, jobs were enriched using flexible work methods, empowerment strategies and new technologies. Even though many organizations applied the sociotechnical theory in the past, people still have jobs that are routine, closely monitored and provide little room for personal development (Checkland \& Holwell, 2004; Checkland \& Scholes, 1990). Perhaps, we need to ask us two but important questions. First, why did socio-technical interest decrease in the 1980s and 1990s? Second, can the socio-technical theory provide guidance for meeting challenges of the $21^{\text {st }}$ century? Today, a complex economic environment surrounds the organizations and it has a significant impact on its performance and the way it functions in the society. In order to realize production efficiency, clear specification to goals need to be followed and control structures need to be in place. Even though the visionary group at Tavistock institute believed in participative goal setting, many organizations pay no attention to employee participation when designing jobs. Hence, when jobs are designed, social risks and consequences of work are often overlooked by the management (Mumford, 2003, 2006). 
The Socio-Technical Balanced Scorecard for Assessing a Public University

Figure 1. The Interacting Variable Classes within a Work System (Bostrom \& Heinen, p. 25)

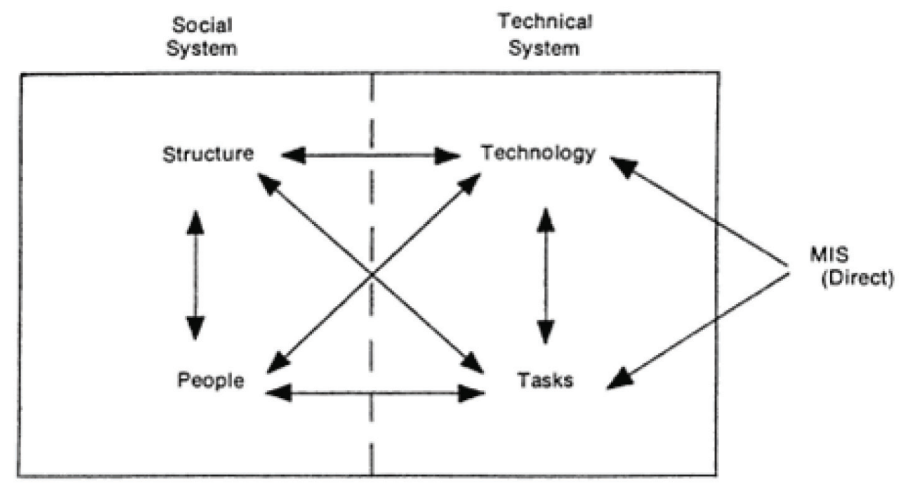

The socio-technical school of thought wanted to change this perception regarding jobs. According to the socio-technical theory, jobs should be designed in a way that fosters creativity, flexibility, and intellectual growth. In the past, practitioners at Tavistock institute have strived to reach two objectives: humanization of work and creation of democratic work policies. Similarly, the goal of socio-technical theory is the joint optimization of the social and technical elements of the organization (Mumford, 2003, 2006). Social elements of the organization are composed of work-related aspects such as task variety, task identity, and autonomy that provide job satisfaction and motivation to the organizational employees (Mumford, 2006). In addition to the work-related aspects, structural elements such as adequate workload, co-worker support, management support, career advancement opportunities and realistic performance measures and reward structures may also increase the overall job satisfaction (Seo, Ko, \& Price, 2004). Technical elements, on the other hand, are concerned with the work processes, tasks, and technology needed to transform inputs into desired outputs. Also, technical elements focus on the identification of possible deviations in the transformation process and aim to control them (Wood-Harper, Fok, \& Kumar, 1987). Although the two elements described above differ considerably, their interplay and harmony is essential for the organization's success in the business (Kling, 1999; Kling \& Iacono, 2001).

Perhaps the most fundamental innovation in the socio-technical thinking occurred in 1976 by Albert Cherns with the development of sociotechnical work design principles. As seen in (Mumford, 2003), the socio-technical design principles can be described as follows.

- Compatibility: Objectives must be compatible with the process of design. This implies that, if the goal is to establish democratic work arrangements (DWAs) then democratic processes must be used to form these DWAs.

- $\quad$ Minimal Critical Specification: Employees should be given clear work specifications but leaving them to determine how to attain these work objectives.

- The Socio-technical Criterion: Deviations from standards should be monitored closely in case where they cannot be eliminated. Inconsistencies of this kind must be resolved by the team that is being affected and not by the supervisors.

- The Multifunctionality Principle: Group require redundancy of functions in order to be responsive and adaptable to the changes in the environment.

- Boundary Location: Boundaries should be defined to assist the knowledge and ex- 
perience sharing within the organization. Boundaries differentiate work activities of a group to another and all group members need to have multiple skill-set and be able to perform one another's work tasks.

- Information:In most organizations, information about operations is usually accessible by the upper management. However, it should rather first go to the work group whose productivity is being monitored.

- $\quad$ Support Congruence: Social support systems must be designed to facilitate social behaviour. If workers are to work together, management must also show supportive behaviour.

- Design and Human Values: Quality of working requires following elements:

- Demanding job

- Where learning occurs

- Involves decision-making

- Embedded with social support mechanism

- Possibility of relating work to social life

- Opportunity to advance and excel in the job

- Incompletion: Emergent and continual design process, leading to an iterative process of changes in environment, demanding new work structures and objectives.

Furthermore, (Pasmore, 1985) put forward a positive evaluation of socio-technical theory over the last three decades. In this study, he recommends that work systems need to be viewed as a group of activities facilitating the whole and not as a group of self-containing jobs. In addition, power sharing is important for increasing efficiency and democracy at workplace. Team members need multiple skill-set and they should be able to carry out one another's work. Lastly, jobs should be designed in a way, which facilitate variety, learning, and knowledge sharing on the job. As seen in (Mumford, 2006) Emery simplified these socio-technical principles and it was suggested that job variety, higher learning prospects, scope for decision-making, training, good supervision, recognition, and bright career prospects are important for enriching jobs. Job satisfaction may be one of the important factors of the socio-technical theory. Job satisfaction can be defined as match between the job expectations workers bring to the work and the requirements of the work as defined by the organizations. According to Mumford's framework, this can be measured under five work dimensions (Mumford \& Weir, 1979).

- $\quad$ The Knowledge Fit: The extent to which the employee's job permits the development of skills and knowledge.

- The Psychological Fit: The extent to which the employee's job permits discretion in achieving personal goals for achievement, appreciation, development, position in the society, etc.

- The Task-Structure Fit: The extent to which the employee's job matches employee's need for task variety, task identity, and autonomy, recognition and performance assessments.

- The Efficiency Fit: The extent to which the job provides an opportunity of financial rewards and a realistic and considerate appraisal programme.

- The Ethical Fit: The extent to which the vision and mission of employer is compatible with those of the employee.

The socio-technical theory has been widely used in the organizations during the 1970s. The following discussion describes the experiences of the participating countries in more detail (Mumford, 2003).

- Norway: The Norwegian Industrial Democracy Programme was based on socio-technical design principles. It was ad- 
opted by most of the industrial firms in the country during 1970s.

- Sweden: By 1973, 500 to 1000 work improvement projects were based on the socio-technical design principles.

- Denmark: In 1970, an agreement between the Danish Employers Confederation and the Danish Federation of Trade Unions was reached. This agreement was based on principles of socio-technical theory.

- France: In 1970s, France also adopted the socio-technical design principles and subsequently became interested in "humanization of work".

- Italy: Trade union agreements between Fiat and Olivetti workers were reached on the basis of socio-technical principles.

- Germany: Humanization of work (based on socio-technical principles) initiative was introduced by the Federal Ministries of Labour and of Science and Technology in May 1974.

- $\quad$ Netherlands: Philips (electronics firm) was the leading socio-technical design firm in the country in the 1960s and 1970s.

- UK: Two action research projects at Tavistock Institute tested and developed the socio-technical design principles in 1949. In 1965, large scale socio-technical project was initiated at Shell UK. Upon the successful completion of this project, Shell plants in Austria, Holland, and Canada also adopted the socio-technical design principles.

- USA: During the 1960s and 1970s, the United Automobile Workers Union negotiated contracts with General Motors, Ford and Chrysler. This was performed on the basis of socio-technical theory.

- India: Prof. Nitish De, an academic in India, deployed socio-technical design principles at various Indian firms during 1960s.
It is believed that socio-technical ideas were important for two reasons during the1960s and 1970s. First, manufacturing industry was growing and firms were forced to introduce better working conditions in order to retain workers that they had. Second, increase in the number of service firms in the industry contributed to the change in work methods as workers required job variety in production process (Mumford, 2006). Approaches that work well at one time may not be so flourishing at another since both business culture and business climate can change. This change was apparent during the 1980s where many firms came under pressure to cut costs and save on the labour expenditures. Machines moved into offices to facilitate routine work processes and lean production methods became the norm in the industry (Moldaschl \& Weber, 1998). During 1990s socio-technical design principles continued to struggle as there was little room for investment in human capital. The focus was mainly on lean production methods and business process reengineering flourished. To conclude this discussion, it can be implied that downsizing of the organizations in the 1980s and 1990s had a negative impact on the socio-technical movement. Nevertheless, there were a small number of firms in the United Kingdom, USA, Europe, and Australia that recognized the importance of participative decision-making, multi-skilled workforce and self-regulating autonomous work groups (Mumford, 2006).

\section{USE OF SOCIO-TECHNICAL THEORY IN THE $21^{\text {ST }}$ CENTURY}

The socio-technical theory is democratic, humane, and provides autonomy and knowledge to employees at all levels. Unique to many, the ideas of socio-technical principles are not new. First, Etzioni defined a method called voluntary simplicity. This approach describes a set of ideas which limit expenditure on consumer goods while 
promoting quality of life, self expression and involvement in society (Elgin, 1981). Another method which is consistent with the humanistic school is associative democracy, which aims to create a participative welfare society which is cohesive and supportive in nature (Pestoff, 1999). Profit sharing and shared ownership are two approaches based on the principles of sociotechnical theory. Perhaps the best example of an organization that shares profit and ownership with its employees is the Mondragon Corporation. The firm employs 20,000 workers; in addition to their basic pay, every employee gets a share from the annual profits. Another goal of Mondragon is to have employees gain ownership in the firm. Hence, the organization saves a small proportion of yearly profits for building reserve funds for its employees. Together, these financial policies help to motivate employees to attain financial goals, and also non-financial goals such as career development and long-term stable employment (Malone, 2004).

More recently, socio-technical theory has been applied in organizations to understand the social requirements of work. One such socio-technical intervention took place in 1994 in an Australian industrial site, (Garrety \& Badham, 2000) involving the development of a system called AMS, designed to control a continuous manufacturing process in a plant. During the late 1990s, the AMS project group came under pressure to increase the efficiency of the AMS system, and Richard Badham and his academic panel were appointed to assist the AMS project team in reforming the system. Two major workshops were held, each attended by socio-technical specialists, technology developers, workers and management officials from the plant. Upon analyzing the findings, it was found that socio-technical principles made the AMS system more humane and responsive to changing conditions in the environment. The socio-technical approach to system development enabled identification of the role of workers in the production process, increasing job satisfaction as the workers could utilize the AMS system more effectively in their everyday work.

Another application of socio-technical theory can be found in a manufacturing organization in the UK. The first stage required the formulation of scenarios which simulate different work configurations and the second stage entailed the development of decision criteria. 12 employees participated in the scenarios and their performance was assessed by the decision criteria. It was found that intervention increased the involvement of workers in job design and was useful in creating favourable work tasks (Nadin, Waterson, \& Parker, 2001). Socio-technical design principles has been used in the North Sea to make a system called Integrated eOperations fully functional and failsafe. The aim was to provide an understanding of emerging concerns that increasing complexities in the exploration of oil and gas can lead to serious vulnerabilities and long-term commercial consequences for North Sea industrial firms. The results of this intervention were the identification of appropriate technology needed to measure the risk of production errors and to manage equipment remotely (Liyanage \& Bjerkebaek, 2006). Furthermore, (Jeppesen, Barfod, \& Leleur, 2007) conducted a case study with a multi-national IT firm in Denmark. The main objective of this firm was to relocate its operations to the Oresund Region in Scandinavia. The principles of sociotechnical design were applied to evaluate location alternatives given the strategic preferences of the firm and social needs of the workers. Although quantitative feasibility studies were an important part of case analysis, socio-technical theory proved to be equally important in conceptualizing the complex environment facing the IT firm. Although the intervention increased the participation of workers in the decision-making process, no definite decision regarding the relocation has been identified. However, authors strongly believe that the socio-technical theory can aid in reaching a solution which would benefit both the company and its workers. 


\section{USE OF ALTERNATIVE MOMC THEORIES IN ORGANIZATIONS}

Even though socio-technical principles enrich jobs which benefit the overall profitability of a firm, researchers in the past have failed to find any positive correlation between socio-technical work design and a firm's profitability (Lucas Henry, 1999; Strassmann, 1990). More recently, researchers have found evidence to support the claim that socio-technical work design does increase productivity (Azoff, Jones, Rodger, \& Butler, 2004; Boresson C., 2005; Butler, 2004). These findings, however, were not without controversy. Neither accounting nor economics acknowledges the fact that social elements of a firm have a positive effect on financial performance. Although accounting has recognized elements such as cost, revenue and other complex measures such as goodwill, the incorporation of intellectual assets and their worth has been poor. Traditional economics accounted for corporate social responsibility, but modern managerial economics show little concern toward the wellbeing of employees. Even the most widely cited book, The Foundations of Corporate Success, does not pay much regard to socio-technical job design (Land, 2000). Moreover, (Porter, 1985)'s five-force analysis does not assess employee behaviour and attitude in the firm and how it impacts the firm's performance.

Business process re-engineering (BPR), consisting of traditional and well accepted ideas of accounting and evaluation, does not recognize the need for policies and reward systems that increase job satisfaction. The furthest most authors go is to indicate the resistance of employees to accepting organizational change. Little research or discussion is taking place on why there is resistance. Business schools commonly introduce the topic of how to satisfy employees through various gain sharing and profit sharing programmes, but little attention is given to social factors that contribute to job satisfaction (Land, 2000; Mumford, 2006). To obtain wider recognition, the socio-technical approach has to show its worth and importance, in terms that are relevant to the managerial paradigm. Socio-technical evaluation may consist of two stages: first, the assesor needs to show that the socio-technical approach is likely to increase shareholder wealth and that it possesses less risk and more certainty than other approaches; second, the assesor needs to provide evidence that sociotechnical iniatiatives lead to financial gains for the organization.

Technical evaluation has been widely accepted in most organizations. It is commonly performed using a set of rules that make it possible to measure performance on a single scale, the financial. The socio-technical method takes into account multiple criteria to measure the firm's performance. Hence, an assessment of the second-order impact of social changes may be required. For example, if changes introduced by socio-technical design increase job satisfaction, the likely secondary impacts might be reduced absenteeism, healthy workforce, and hopefully increased productivity. A few assessment methods are based on the multi-objective, multi-criteria(MOMC) principle. Information economics (Parker \& Benson, 1988) and the balanced score card (Robert S. Kaplan \& Norton, 1992) are two deviations of the MOMC concept. Information economics realizes that gains from technology-based change include factors which traditional cost/benefit calculations cannot handle, because there is a range of intangible benefits such as improved response time for handling customer complaints or ubiqutous information retrieval for on-site decision-making. According to information economics, gains are split into two categories, the technical and the social, which are assessed independently. However, no explicit guidelines are provided for assessing gains, risks and costs relating to the social aspects of work. Information economics may well be modified to incorporate a thorough evaluation based on the social aspects of work. Even though information economics has proved useful in assessing the value of information systems, it is not widely used in 
organizations. Perhaps its emphasis on IS assessment rather than as an organization-wide tool for assessing work design may have suppressed its acceptance (Land, 2000).

A widely accepted methodology which has gained corporate attention is the balanced scorecard (Nair, 2004). Since the balanced scorecard is concerned with the financial well-being of the firm, it may be an appropriate method for assessing the socio-technical worth of IS in the organizations. Although (Martinsons, Davison, $\&$ Tse, 1999) tailored the balanced scorecard for evaluating the worth of decision support systems, the originators never include the "social" in the scorecard. The balanced scorecard was mainly developed to measure organization's customer satisfaction, financial standing, internal business processes, and ambition to learn and grow. (Land, 2000) described balanced scorecard as: dials and indicators in an cockpit of an aeroplane. In order to navigate the aeroplane, pilot need information on aspects such as fuel, altitude, air speed, bearing, and final destination. Likewise, the complexity of running an organization requires performance information from several areas concurrently. The balanced scorecard enables the manager to answer four important questions (Robert S. Kaplan \& Norton, 1992).

- How do customers view us? (Customer perspective)

- How do the shareholders perceive us? (Financial perspective)

- What must we improve and excel at? (Internal perspective)

- Can we keep on improving and creating value? (Innovation and learning perspective)

- A detailed account of the balanced scorecard is provided in the next section.

\section{THE BALANCED SCORECARD}

In order to analyze the customer perspective, the balanced scorecard requires the manager to split the mission statement into exact measures that really matter to the customer. Customer concerns commonly fall into four categories; they are quality, response time, customer service, and cost. Hence, to put the balanced scorecard at work, the manager need to define goals for quality, response time, customer service, and cost and then transform these goals into precise measurable objectives. Customer-related measurement criteria are important, but they must be transformed into specific measures of what the firm must do internally to satisfy its customers. Hence, the manager needs to identify critical success factors and improve on the operations that really matters to the customer. Factors that have the best impact on customer satisfaction include response time on customer query, product/service quality, worker skills, and productivity. To attain these goals on customer satisfaction, the manager must identify improvement areas that are influenced by workers' actions (Robert S. Kaplan \& Norton, 1992).

Financial performance factors specify whether firm's strategy, performance, and implementation are improving firms bottom-line. Case flow statements, income statement, increase in assets and decrease in liabilities, and growth in share price commonly measure financial perspective. The financial objectives can be seen as guidance for the objectives and measures in the other perspectives. The primary goal for a company is to provide returns on the capital invested, to create value to its investors, hence to be profitable. The balanced scorecard aids in making the financial objectives of a company more clear and comprehensive by targeting them to specific needs of each business unit in the organization (Robert S. Kaplan \& Norton, 1992). 
Internal business process measures factors that a firm considers essential for its competitive success. Defining objectives and measure for the internal business process perspective is generally done after the formulation of financial and customer perspective. This is done in-order to emphasize that the metrics developed in the internal business process perspective support the objectives established for customers and shareholders. Kaplan and Norton argue that even though companies have moved beyond just relying on traditional financial measures to supplement them with measures such as quality, yield, throughput, and cycle time, they still focus on improving performance of individual departments rather than integrated business processes. In order to encourage collaboration among the different departments in a company and better monitor the cross-functional performance, it is essential to assess various business operations such as order fulfillment, procurement, and production planning and control. Cost, quality, throughput and time measures can be defined and assessed for theses operations (Robert S. Kaplan \& Norton, 1992; R. S. Kaplan \& Norton, 1996).

Competition in the market requires the firm to introduce new products/services and continue to improve its offering to stay competitive in the industry. A firm' measurement factor to learn, improve, and innovate is directly tied to the firm's ability to introduce new products and services, add more value for the customer, and improve internal operations, target new markets, develop foreign operations and in so doing increase shareholder wealth. The innovation process consists of two stages. In the first stage, the company has to identify the market, by discovering emerging and latent needs of existing and new customers. In the second stage, the company has to produce product/service offering (Robert S. Kaplan \& Norton, 1992).

\section{THE SOCIO-TECHNICAL BALANCED SCORECARD}

The four perspectives of the balanced scorecard are inter-linked since satisfied customers and production efficiencies leads to financial well-being of the organization. In order to develop a balanced scorecard, the assessor needs to sketch a table with a list of goals and their respective measures. Thus, under customer perspective a goal might be to "reduce service time for repairs". The appropriate measure might be average time to make a repair. Based on the measurement data, the evaluator can perform standard deviation analysis to identify delays in service and which factors might have contributed to the delay. The selection of goals is an important process and stakeholder input is essential in identifying high priority goals and ranking them according to their inherent risk and organizational mission and strategy.

The critics of balanced scorecard indicate lack of many other important perspectives. For instance, one could incorporate stakeholder perspective to identify how firm is perceived by its suppliers, investors, and society at large. Nevertheless, it may be subtle to measure goals that firm cannot fully control, reducing the original significance and viability of the balanced scorecard (Martinsons et al., 1999). It is believed that the balanced scorecard can be extended to include employee (socio-technical) perspective. With the incorporation of employee perspective, the organization could identify how the employees may perceive it. Since today's employee require autonomy, freedom, safe working conditions, it is essential that appropriate measures are defined to assess employee satisfaction. Highly motivated and satisfied workforce is often linked with excellent customer service, in that, if enthusiastic staff approaches the customers, it is likely that they will return or do business again with the firm. Also, 
it is believed that motivated workforce is more likely to learn and improve internal operations and make the organization more competitive in the industry. Hence, employee perspective is linked with firm's major functions and it is important that the organization focus on improving its employees' work environment (Horton, Davenport, \& Wood-Harper, 2005; Land, 2000). Moreover, the socio-technical balanced scorecard can be used to define goals that are important from both managerial as well as the employees social welfare.

Three areas are particularly important to include in this perspective. First, "employee competencies and skills"; do employees have the right mix of skills to complete their work tasks? Second, "the flow of information"; do employees have the tools and information they need to make timely decisions? Lastly, "the organizational climate"; do employees have incentives and rewards upon the successful completion of a task. With the incorporation of employee perspective, it is believed that goals such as higher job satisfaction, stress reduction; increase in participative decision-making may materialize. Assessment measures could include first order measures such as changes in work-satisfaction and secondary measures such as decline in absenteeism and improvement in behaviour and physical health may also be fruitful. The process of defining goals and measures in the employee perspective can be regarded as a socio-technical one. The principles of socio-technical theory may be valuable in this process. That is, they can help define goals that intend to improve employee job satisfaction (Robert S. Kaplan \& Norton, 2001).

Although the balanced scorecard has been fruitful in non-profit organizations, most nonprofit organizations had difficulty applying the balanced scorecard. One success example can be found at the Mecklenburg County in the USA, the balanced scorecard has transformed the company from where accountability was unclear to a few balanced scorecard experts, to a system of widespread accountability and transparency based on data -driven decision-making processes. Another was found at Northwest Fire District, Pima County in the USA. The district problem was to develop a system that would enable them to see how the organization was performing. A group of $40 \mathrm{em}-$ ployees representing all levels of the organization was formed to guide the enhanced strategic planning process for the next five years. In addition, given the communication challenges between fire services labour/management process, the balanced scorecard guided the communication process that bring along key players in the organization toward the enhanced strategic planning process. More recently, the application of the balanced scorecard can be found in US government. In nominating Jeffrey Zients to be ChiefPerformance Officer, US president Obama emphasize that federal government would continue to develop upon performance focus, re-invent processes, cut costs, and discover best practices in the entire government.

Not all non-profit organizations have been successful in applying the balanced scorecard. The problems facing non-profit organization using balanced scorecard originate generally from the increased complexity of stakeholder requirements and the potential variability of these demands over time. Not limited to the failures at NGOs, translating the balanced scorecard to the complex world of academia is a challenge. Since the 1990s accountability has become a challenging issue in the higher education sector. Universities are required to provide performance indicators (i.e. evidence of their value in the society) to government, alumni, prospective students and external stakeholders. Numerous state and board agencies have developed "report cards" that grade universities according to the performance on various categories. Surveys in the main stream press and Web rank universities based upon their graduation rates, resources, reputation, publications, and more. However, these performance indicators make little or no reference to the goals of the universities and literally no reference is given to the teaching methods and programme quality 
with respect to the specified results of teaching and research.

The original configuration of balanced scorecard placed financial goals on the top of the hierarchy but since maximizing shareholder wealth is not the main objective, it was not widely applied by these organizations. The socio-technical balanced scorecard may be useful in assessing forprofit organization's mission and vision strategy, but its application in a non-profit organization can be even greater. As non-profit organizations commonly operate on humanistic welfare paradigm and well-being of the society, the ideas of socio-technical job design may receive greater acceptance in these organizations. Universities can be defined as private or public institutions. Private universities are generally for-profit and public universities are of non-profit nature (Wikipedia, 2007). The University of Manchester is a non-profit institution and it is mainly funded by the council grants (government), academic fees (students), research grants (donors), and other operating income (accommodation) (The University of Manchester, 2004). Moreover, in a for-profit university, students pay entirely for the education that they receive. But in a public university, government and donors predominantly provide financial resources for supplementing students' tuition fees. Here one could ask, who the customer is-the student or government or donor agencies. Rather making a choice, public universities may consider government, donor agencies and students as a customer when applying the socio-technical balanced scorecard. An extensive framework for accessing a public university is developed next for a complete illustration of the socio-technical balance scorecard.

\section{CONCLUSION}

Socio-technical theory has been used in the organizations to design jobs that provide work satisfaction and motivation to the organizational employees. Although socio-technical theory has been fruitful in many organizations, it has not been applied widely due to the need for cost savings in the past. The balanced scorecard is a methodology that has been used extensively in the organizations. The balanced scorecard enables the organization to assess its strategy and whether it's meeting its financial goals. The balanced scorecard has been beneficial in the for-profit organizations; its use in the non-profit organizations has been poor. The original configuration of balanced scorecard placed financial goals on the top of the hierarchy and since maximizing shareholder wealth is not a main objective for most non-profit organizations, it was not widely applied by these organizations. Thus, the socio-technical balanced scorecard was developed to include the employee perspective.

With the incorporation of employee perspective, work-related factors that have a negative impact on the employees work performance may be identified and enable the organization to design jobs that promote employee task variety, discretion, participation in the decision-making process, training, realistic performance measures, and rewarding pay structures. Next, a framework for accessing a public university was proposed for an illustration of the socio-technical balance scorecard. The employee perspective was included to assess the academics/staff's productivity, absenteeism, and job satisfaction whereas customer perspective takes into consideration multiple measures that include student/government/donor viewpoints and goals. The internal business perspective relates to the goals that measure a university's academic as well as administrative processes including IT infrastructure. The innovation and learning perspective, on the contrary, is concerned with financial support for the students and the number of new courses developed including e-learning courses per year. Lastly, the financial perspective relates to the increase in university graduates and funding obtained from the government and donor bodies each year. 
Figure 2. The Socio-technical Balanced Scorecard for a Public University Wide Assessment (The University of Manchester, 2004)

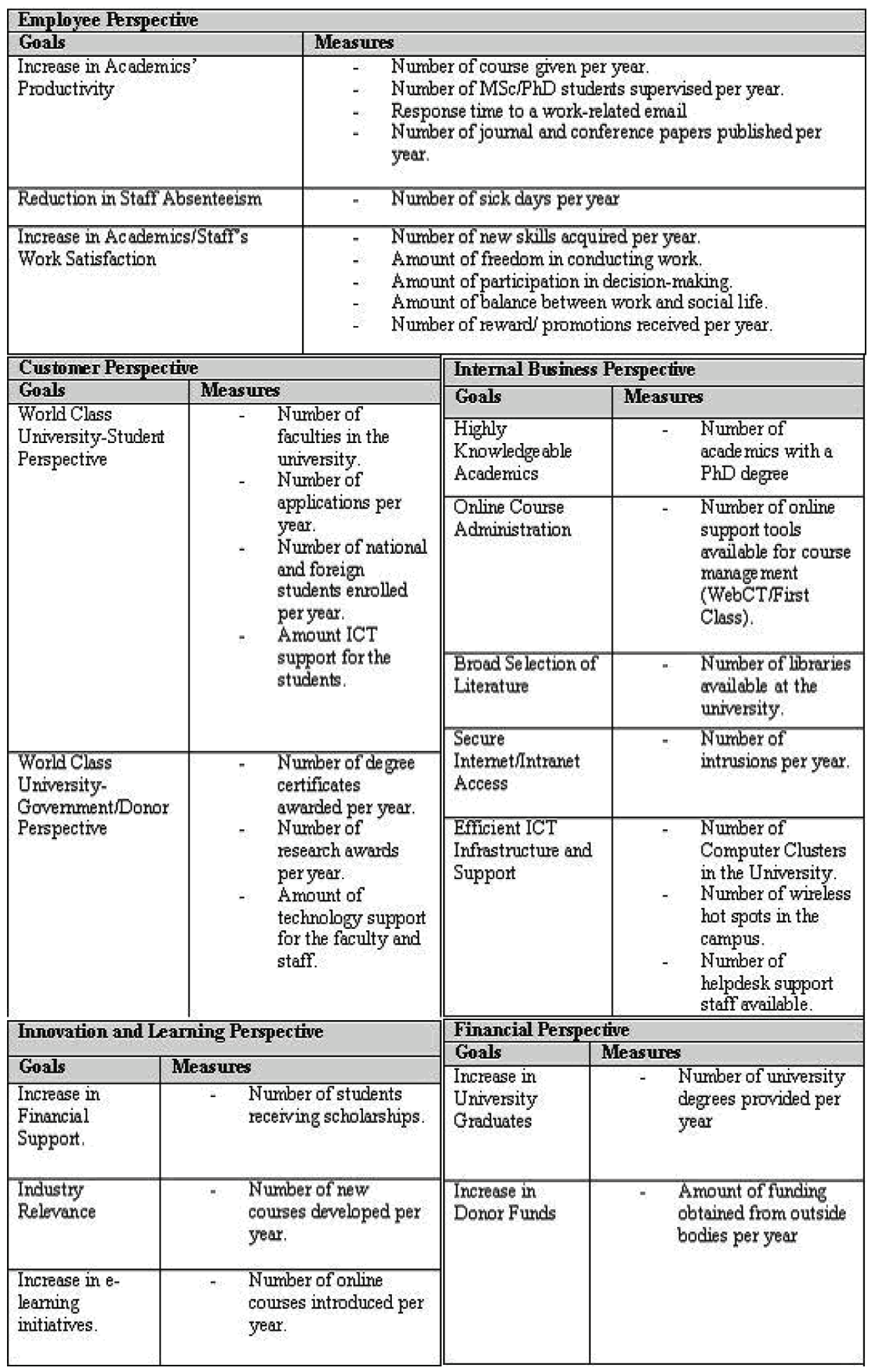




\section{REFERENCES}

Azoff, M., Jones, T., Rodger, A., \& Butler, G. (2004). IT Performance Optimisation: Realising Best Value from IT Investments. Hull, UK: Butler Direct.

Boresson C., J. (2005). Good Enough! IT Investment and Business Process Performance in Higher Education. Educause Center For Applied Research.

Bostrom, R.P., \& Heinen, S. (1977). MIS problems and failures: a socio-technical perspective, part 1: the causes. Management Information Systems Quarterly, 1(3), 17-32. doi:10.2307/248710

Butler, G. (2004). Managing Costs in IT: Achieving Best Value from IT Investments. Hull, UK: Butler Group.

Checkland, P., \& Holwell, S. (2004). Information Systems and Information Systems-Making Sense of the Field. Chichester, UK: John Wiley \& Sons.

Checkland, P., \& Scholes, J. (1990). Soft System Methodology in Action. Chichester, UK: Wiley.

Elgin, D. (1981). Voluntary Simplicity: Toward a way of life that is Outwardly Simple, Inwardly Rich. New York: Morrow.

Garrety, K., \& Badham, R. (2000). The politics of socio-technical intervention: an interactionist view. Technology Analysis and Strategic Management, 12(1), 103-118. doi:10.1080/095373200107265

Horton, K., Davenport, E., \& Wood-Harper, A. T. (2005). Exploring sociotechnical interaction with Rob Kling: five big ideas. Information Technology \& People, 18(1), 50-67. doi:10.1108/09593840510584621

Jeppesen, S. L., Barfod, M. B., \& Leleur, S. (2007, April 11). Comparing a soft and hard multi-methodology approach: location of an IT company in the Oresund region. Paper presented at the ISOneWorld 07, Las Vegas, USA.
Kaplan, R. S., \& Norton, D. P. (1992). The balanced scorecard: measures that drive performance. Harvard Business Review, 70, 70-79.

Kaplan, R. S., \& Norton, D. P. (1996). Translating strategy into action: the balanced scorecard. Boston: Harvard Business School Press.

Kaplan, R. S., \& Norton, D. P.(2001). The strategyfocused organization: how balanced scorecard companies thrive in the new business environment. Boston, MA: Harvard Business School Press.

Kling, R. (1999, January). What is Social Informatics and Why Does it Matter? D-Lib Magazine, 5.

Kling, R., \& Iacono, S. (2001). Information technology and organizational transformation: history, rhetoric, and practice. Thousand Oaks, CA: Sage Publications.

Land, F. F. (2000). Evaluation in a socio-technical context. Paper presented at the Organizational and Social Perspectives on IT 2000, Aalborg, Denmark.

Liyanage, J. P., \& Bjerkebaek, E. (2006). Use of advanced technologies and information solutions for North Sea offshore assets: ambitious changes and socio-technical dimensions. International Journal of International Technology and Information Management, 15(4), 1-10.

Lucas Henry, C. (1999). Information Technology and the Productivity Paradox: Assessing the Value of the Investment in IT. Ox ford, UK: Oxford University Press.

Malone, T. W. (2004). The Future of Work: How the New Order of Business Will Shape Your Organization, Your Management Style, and Your Life. Boston: Harvard Business School Publishing.

Martinsons, M., Davison, R., \& Tse, D. (1999). The Balanced Scorecard: A Foundation for the Strategic Management of Information Systems. Decision Support Systems, 25, 71-88. doi:10.1016/ S0167-9236(98)00086-4 
Moldaschl, M., \& Weber, W. G. (1998). The three waves of industrial groups: historical reflections on current research on group work. Human Relations, 51,347-388. doi:10.1177/001872679805100307

Mumford, E. (2003). Redesigning Human Systems. London: IRM Press.

Mumford, E. (2006). The story of socio-technical design: reflections on its successes, failures and potential. Information Systems Journal, 16, 317-342. doi:10.1111/j.1365-2575.2006.00221.x

Mumford, E., \& Weir, M. (1979). Computer Systems in Work Design-The ETHICS Method: Effective Technical and Human Implementation of Computer Systems: A Work Design Exercise Book for Individuals and Groups. London: Associated Business Press.

Nadin, S. J., Waterson, P. E., \& Parker, S. K. (2001). Participation in job redesign: an evaluation of the use of a sociotechnical tool and its impact. Human Factors and Ergonomics in Manufacturing, 11(1), 53-69. doi:10.1002/15206564(200124)11:1<53::AID-HFM4>3.0.CO;2-F

Nair, M.(2004). Essentials of balanced scorecard. New York: Wiley.

Parker, M. M., \& Benson, R. J. (1988). Information Economics: Linking Business Performance to Information Technology. Englewood Cliffs, NJ: Prentice-Hall International.

Pasmore, W.A.(1985). Social science transformer: the socio-technical perspective. Human Relations, 48, 1-22. doi:10.1177/001872679504800101
Pestoff, V. A. (1999). Social empire and civil democracy in Sweden: developing a participatory welfare society in the twenty-first century. In W. E. Halal \& K. B. Taylor (Eds.), 21st Century Economics. London: Macmillan.

Porter, M. E. (1985). Competitive Advantage: Creating and Sustaining Superior Performance. London: Collier Macmillan Publishers.

Seo, Y., Ko, J., \& Price, J. L. (2004). The determinants of job satisfaction among hospital a model estimation in Korea. International Journal of Nursing Studies, 41, 437-446. doi:10.1016/j. ijnurstu.2003.11.003

Strassmann, P. A. (1990). The Business Value of Computers: An Executive's Guide. New Canaan, CT: Information Economics Press.

The University of Manchester.(2004). Introducing The University of Manchester. Manchester, UK: University of Manchester.

Wikipedia. (2007). Public University. Retrieved March 19, 2007, from http://en.wikipedia.org/ wiki/Public university

Wood-Harper, A. T., Fok, L. M., \& Kumar, K. (1987, December). Methodologies for socio-technical systems (STS) development: a comparative review. Paper presented at the 8th International Conference of Information Systems, Pittsburgh, USA. 